\title{
Halal Analysis Principle for Food and Pharmaceutical: A Case Study of Gelatin
}

\author{
Z Alwi \\ Department of Judicial and Family Law, Faculty of Shariah and Law, UIN Alauddin \\ Makassar, Indonesia \\ \{zulfahmi.alwi@,uin-alauddin.ac.id\}
}

\begin{abstract}
This study is aimed to establish the principles of fiqh and alternative solutions in the halal industry, particularly the study of gelatin as a part of ingredients that are often used in the food and pharmaceutical industry. The critical points of this study that should be supervised are the capability to understand and investigate the unlawful materials, micro-products or biotechnology, chemical and physical changes of materials, as well as halal analysis that in line with the Islamic jurisprudence. This study proposes to use the principles of Istihalah, istihlak, and tahärah as alternative solutions in the halal industry. Government oversight through the Halal Product Guarantee Agency as well as the Food and Drug Supervisory Agency is also significant to take into consideration. Halal gelatin must be sourced from ingredients that are not pork and carcass. Gelatin needs to in as it is sourced from animals or nonvegetable, except for fish. Gelatin sourced from cows, goats, other mammals or poultry, must be accompanied by a written guarantee that the slaughter process is carried out following Sharia. The manufacturing process that uses enzymes also needs to be traced to its halalness. The production facilities must also have been cleaned from unclean according to their severity. Another alternative to gelatin is vegetable ingredients. Amylum and cellulose can be alternative ingredients. The character of gel, viscosity, elasticity, and several other characters are similar to the character of gelatin.
\end{abstract}

Keywords: Halal Analysis, Food, Pharmaceutical

\section{Introduction}

The halal industry in Indonesia has been in place after the adoption of Law 33 of 2014 regarding the guarantee of Halal products. This law determines that food and medicines must meet Halal criteria set by the government to ensure that the public is protected from the consumption of non-halal products. Not only Indonesia, but other countries also have exercised halal control over food and medicines, such as Malaysia[1], Singapore, India, even America and Australia[2]. The policy of some state governments to control halal products is indeed significant, as there are more and more food products that contain non-halal ingredients or use illegal methods that alert Muslim consumers globally[2]. 
Muslim communities are dealing with big challenges since products of food, medicines and even cosmetics are increasing significantly, while its raw materials or its making process are not yet clear. Other challenges that Muslim communities deal with the existence of nonhalal materials, such as pork, carcasses, blood, or parts of animals that are not slaughtered according to Sharia in various foods as well as the use of insulin, heparin, alcohol, and gelatin in the manufacture of many products. Likewise, the involvement of impure substances such as keratin, albumin, placenta extract, and hyaluronic acid in the manufacture of cosmetics[3].

Gelatin is one of the most common and widely used ingredients in various food and pharmaceutical products due to its functional and technological properties[4]. Ali Batu et al. argued that the use of gelatin in the world has always been and continues to increase. It has even been found that about 326,000 tons of gelatin is produced worldwide each year[5], with gelatin consumption in Turkey reaching 5,000 tons per year[6].

The Muslim community faces problems when it believes that gelatin does not conform to halal standards. In Indonesia, the use of gelatin especially in pharmaceutical products has not received halal certification from MUI. The followers of other religions such as Judaism and some Christians also feel uncomfortable with pork's gelatin. Gelatine is the most widely studied product in halal studies. Therefore, appropriate studies have been carried out in advance by many researchers. The previous studies were Ali Batu et. al (2015), Ahmad Mursyid (2013), Nurfarhana Hassan (2018), Hassan Ibrahim Abdullah Amqizal et. al (2017), Fajar Nugraha (2018), Mohammad Aizat Jamaluddin and Che Wan Jasimah Wan Mohamed Radzi (2009), Sayyid Muhammad Ridwan bin Sayyid Yusuf et al. (2018).

This study discusses the halal's principle concerning gelatin as an essential component of a variety of modern industrial medicine and food products. Gelatin, which is perceived as an illegal substance with an impure process, needs to be analyzed for both its input and its manufacturing process. This study is expected to provide an alternative solution in the Islamic perspective to the problem of the use of gelatin in the drug and food industry.

[6]also studied about gelatin and its barriers, their application in many industries and their impact on Muslims, as well as possible alternatives as a solution. Ahmad [3] also has analyzed the halal product using a chemical analysis approach. He emphasized the use of chemical analyzes to identify illegal substances in the product but acknowledged the limitations of not being able to identify illicit substances related to the slaughtering system. Analysis of the halal nature of commercial gelatin has also been reported by [7]with the identification of DNA porcine content using a species-specific polymerase chain reaction (PCR) assay. In the meantime, Nurfarhana Hassan identified the gelatin content with FTIR spectroscopy (chemical method) and PCA (chemometric method)[8]. All of the above studies did not use the fiqh analysis approach to identify the input and gelatin process.

The study using fiqh analysis was conducted by Wahyu Fajar [9] using the istihālah approach as an argument for the loss of the pork element through the final process, which is supported by darūrat arguments. Besides, Mohammad Aizat Jamaluddin and Che Wan Jasimah Wan told Mohamed Radzi about istihälah's approach to Islam and modern science. Istiḥālah, according to him, is divided intoistihālah al-șah̄ịah and istiḥālah fāsidah. His research found that the use of istihalah on a range of foods is relevant as an alternative solution to halal analysis[10]. Mohammad Aizat Jamaluddin et al. (2012) highlights that the use of istihālah is inapplicable to analyze gelatin while to analyze the change of alcohol from wine to vinegar is applicable[11].

Another comprehensive study on the analysis of gelatin and alcohol using the istihālah and $i s t i h l \bar{a} k$ approaches was conducted by Sayyid Muhammad Ridwan bin Sayyid Yusuf et al. The study describes the classical and contemporary scholars, both referring to the rules of istihâalah 
and istihlāk with regard to gelatin and alcohol, but does not scientifically discuss the details of the input and the process of gelatin, it merely describes in general terms that gelatin contains pork and/or impure substances[12]. This study is different from the above studies. This study is more comprehensive in examining the stages of the gelatin production process and incorporating them into relevant fiqh rules ranging from țahärah, istihălah, istihlāk to darūrat rules.

\section{Methods}

This study is descriptive-qualitative with an interdisciplinary approach by identifying gelatin products in detail, including its production processes and highlighting them with the Islamic jurisprudence approach. The results of this study provide a comprehensive picture and solution to the confusion about the status of gelatin products that have been widely consumed, used and even developed by the community. Therefore, this study also becomes a reference concerning the legal aspects of gelatin as well as a guide for actors in the pharmaceutical and food industries to avoid the pros and cons, so that the benefits of the product can be maximized as the convenience of the public while using the product.

\section{Results and Discussion}

\section{The Basic Principle of Halal Analysis}

The basic principle of halal analysis, which is relevant to today's drug and food industry products, is based on Usul Fiqh rule "the law of origin of all things is lawful unless there is a prohibited statement." This principle refers to the hadith that Allah has explained things that are lawful and forbidden, but Allah has silenced some things that cannot be questioned in this way because they are part of Allah's mercy and gospel it does not mean that Allah is negligent in this regard[13]. However, there are few items that are prohibited in relation to gelatin, such as pork, carcasses, blood, spiked animals, battles for other than Allah, human skin and bones, and khamr.

Pork

The prohibition of pork is based on QS al-Baqarah/2:173, QS al-Ma'idah/5:3, QS alAn'am/6:145 and QS al-Nahl/16:115. The prohibition of pork also represents the prohibition of its fat[14], even of all body parts[15]. Ibn Hazm explained that the Muslim scholars agreed to ban porks and all parts of its body, including its flesh, brain, nerves, cartilage, bowels, and skin[16]. The hadith also highlights the ban on the use of porks in connection with nonconsumption, as stated in hadith narrated by Muslim from Jābir bin 'Abdullah[17].

\section{Carcasses}

Carcasses are animals that die on their own, not because they are slaughtered or hunted by humans[18]. The verses that prohibit carcasses is the same as the verses that prohibit pork, as well as the hadith narrated by Muslim above[17]. It is just that the carcasses do not apply to two animals, the grasshopper carcass and the carcass of the sea, based on the authentic hadith narrated by Ibn Mājah and Ahmad from Ibn ar Umar[19]. Al-Qarḍāwī argues that the five criteria for the death of animals in QS al-Mā'idah/5:3, namely al-munhaniqah (stifled), almauqüżah (beaten), al-mutaraddiyah (fallen), al-națīhah (gored) and mā akala al-sabu'u (spilling on wild animals)[18].

The prohibited carcass has the same status as the prohibited animal being slaughtered without mentioning the name of Allah, as confirmed by Surat al-Anam/6:121. In response to the verse, scholars interpreted different opinions on the law of mentioning Allah in slaughter. 
Some scholars follow the hadith of Ibn Umar, Nafi, and 'Āmir al-Sya'bī, who argue that the mention of the name of Allah is obligatory and a condition for the validity of the carnage, so that it is invalid if it is omitted either for oblivion or intentional becomes. Another opinion of Imam Malik and Ahmad is that if it deliberately does not mention the name of Allah, the law is prohibited, but if it is forgotten that it is still consumed halal. While al-Syāfi' $\overline{1}$ believes that the mention of the name of Allah is only a Sunnah because he associates it with QS alAn'am/6: 145, the purpose of the verse is not to refer to the mention of the purpose of slaughter, which is not in the name of Allah. In the hadith of Aisyah, when a people asked the prophet about the status of the flesh brought by an unknown person, whether the name of Allah should be mentioned in his slaughter or not, the prophet allowed them to eat by first mentioning basmalah[20].

Animals that are not slaughtered because of Allah are forbidden because of several verses, QS al-Baqarah/2:173, QS al-Mā'idah/5:3 and QS al-An'am/6:145. The word ihläl is the loud voice of the Jahiliah when they call their God in the practice of slaughtering animals that direct them to their worship [21].

Blood

Ibn al-'Arabi (1076-1148 AD) claimed that the scholars had agreed on the prohibition and impurity of blood so that it could not be consumed or used[22]. The legal status of blood that prohibited in Islam is based on QS al-Baqarah/2:173 and QS al-Mā'idah/5:3. Prohibited blood is al-dam al-masfüh (flowing blood). Scientists argue that if the flowing blood were not restricted in the verse, all blood groups would be forbidden, so it would be very difficult for humans to track down and cleanse the blood associated with the flesh[23].

The affirmation of limiting on the absoluteness of the blood is also confirmed by the Prophet. The authentic hadith narrated by Ibn Mājah and Ahmad from Ibn Umar stated that blood in the form of liver and spleen are two blood groups that are halal[19][24]. Based on this hadith, blood that does not flow like the liver, spleen, and blood that remains in the veins is halal. Thus, the requirement of bloodiness must be removed from the meat. When it melts with meat, it can be consumed because it is difficult to separate it. Blood that flows from slaughtered animals or living animals is absolutely haram, even blood from animals whose consumption is prohibited will either prohibited, whether slaughtered or not, either little or much[25].

Spores or Fangs

Regarding wild animals, one of hadith narrated by al-Turmużi from Abū Hurairah and Abū Salamah mentioned that during the war of Khaibar, the Prophet forbade any wild animals and animals that were targeted by firing and tame donkeys. In another hadith narrated by alBukhārī and Muslims from Abū Sa'labah it was mentioned that the Prophet also forbade consuming wild fanged animals and sharp-clawed birds[17].

\section{The Part of Human Body}

The use and/or commercialization of human body parts is prohibited by Muslim scholars. The reason for the ban is not that it is impure or unclean, but that it is related to ethics and respect for human fame[26], which is why trade and use are seen as underestimating and humiliating. For this reason, the MUI Fatwa Commission has issued a fatwa that ban the use of human hair as well as food and drug products related to the human hair[27].

\section{Alcohol and Khamr}

The prohibition of khamr was agreed by scholars based on al-Qur'an and hadith of the Prophet. However, the analogy of alcohol with khamr requires a further study. In terms of the MUI definition, alcohol is a different from khamr. Alcohol is the term for any organic compound in which called the hydroxyl group $(-\mathrm{OH})$ is attached to a carbon atom. Khamr is 
an intoxicating drink, in the form of wine or others, whether cooked or not, which is referred to as an alcoholic beverage[28].

Alcoholic beverages are intoxicants consisted of ethanol. This material is a compound of the alcohol class with two carbon atoms. Alcohol can be found in many foods and beverages but is not necessarily referred to as an alcoholic drink if it does not contains ethanol. Intoxicating levels of ethanol contained in certain beverages/foods are referred to as 'illat, which made those beverages/foods as khamr.

Khamr is prohibited because of the intoxicating's 'illat, whether it results in drunkenness or not. Unlike alcohol, it does not automatically become khamr. When alcohol as its original law does not mix with other substances is halal and vice versa. Furthermore, if it is not used as a food, for example as an antiseptic like $70 \%$ alcohol, then it is allowed by law.

It is undeniable that there are controversies between Muslims about khamr. Among them, there are differences between alcohol and khamr, since the alcohol component is present in many foods and beverages that occur naturally and not intoxicating so that alcohol in certain quantities is generally not intoxicated and inadvertently processed into intoxicating. On the other hand, some insist that ethanol is identical to khamr and it is automatically haram. The reason for this is that the main cause of intoxicating drinks is alcohol, so alcohol itself is khamr[29].

\section{"Halal" Procedure}

Although the ingredients and processes of the temporary gelatin are thought to have halal problems, some relevant rules are used in the study of the process of making gelatin in relation to the halal analysis, tahārah, istihlāk, and istihāalah.

\section{Tahārah}

Tahärah is the process of purification of the existing body or something impure. The goal is to have the sacred body to worship and rightful in terms of sharia'. In Islam, there are various methods of Tahärah, such as bathing, ablution, washing and so on. The medium of tahärah (purification) varies in the form of water, earth, stone, wood, and other solid objects.

The use of the medium has its own provisions. Islam has established the criteria for holy water and sanctified it as a legal requirement for water used in tahärah. The quality and quantity of water established in Islamic jurisprudence should be consistent with both the standards of clean water and the estimated minimum volume of stagnant water capable of overcoming pollution, including the permissibility of flow water, even if it is assumed that that small amounts of ventilation correspond to counteract oxidation reactions and volatilize substances that are more volatile than water[30]. Similarly, soil that is chemically considered to represent aluminosilicate compounds that could remove dogs' saliva and microorganisms within[30]. The combination of soil and water in the purification of dog odor is effective because it creates soil tension that strengthens the adsorbing nature because its surface is widely[31]. Some studies on the development of impure cleaners in modern science, such as soap formulated with bentonite and kaolin soils, are considered an effective alternative[32], as is bentonite liquid soap with a combination of coconut oil and palm oil[33]. Modern scientists continue to innovate technology to present alternative tahārahs that are more flexible and yet fulfill the substance of impure purification.

\section{Istihalah}

Istihălah is one of the rules in the series of food and beverage materials cleaning from impure base material to pure and legal material. Wahbah al-Zuhaili argues that istihălah is a change of impure substances, both through natural change and through human mediators. It was about the transformation of deer blood into perfume, of khamr in natural and synthetic vinegar, of cadavers in salt, of human waste into ashes and so on[34]. In general, istihālah 
means changing material with another material through the process of mixing and creating new shapes that physically and contently differ.

Basically, the clerics agree that istihālah is the principle of purifying impure objects. AlSyāfi'i accepts istihălah in three cases, namely the conversion of khamr into vinegar naturally, the skin of animals other than tanned dogs and pigs and the transformation of animals such as carcasses into caterpillars due to metamorphosis into a new life[34]. Some of the Hanbalī scholars also argue that confining istihălah to something with the natural process, so that the process is considered unclean by human mediation[35]. Abu Hanīfah argues that istihāalah can turn impure into pure and legal and plays an important role in the process of impure purification. Istihālah, supported by Abu Hanīfah, refers not only to the washing of impure objects but also to foods such as the transformation of khamr into vinegar. Changes in the bitterness of khamr to vinegar may be considered holiness if the bitterness vanishes. The view of Abū Hanīfah seems to be more relevant and adaptable to technological developments since it is flexible with innovation in medicines and foods. Al-Syâfi'i's is pointed about the imperfect of the istihālah process because the material still contains impure material.

The validity of istihalah is determined by three criteria, namely the original material, the modifier, and the final product. There are 2 types of istihälah which areIstihālah șahĭhah and istihāalah fāsidah, as below:

Table 1.Istihālah șahịhah

\begin{tabular}{l|l|l|l|}
$\begin{array}{l}\text { Original } \\
\text { Material }\end{array}$ & Modifier & $\begin{array}{c}\text { Final } \\
\text { Product }\end{array}$ & \multicolumn{1}{c|}{ Example } \\
\hline Halal & Halal & Halal & $\begin{array}{l}\text { Fish meat mixed with flour and } \\
\text { water to produce fish balls. }\end{array}$ \\
\hline Haram & Halal & Halal & $\begin{array}{l}\text { Pork that falls in seawater and } \\
\text { breaks down into saltwater. }\end{array}$ \\
\hline Halal & Haram & Halal & $\begin{array}{l}\text { Plants that are fertilized with } \\
\text { pig manure, but produce halal } \\
\text { fruits. }\end{array}$ \\
\hline
\end{tabular}

Source: Jamaludin \& Radzi (2009)

Table 2.Istihālah fāsidah

\begin{tabular}{|l|l|l|l|}
\hline $\begin{array}{c}\text { Original } \\
\text { Material }\end{array}$ & Modifier & $\begin{array}{c}\text { Final } \\
\text { Product }\end{array}$ & \multicolumn{1}{c}{ Example } \\
\hline Halal & Halal & Haram & $\begin{array}{l}\text { Grapes are mixed with water but } \\
\text { turned into wine (khamr). }\end{array}$ \\
\hline Halal & Haram & Haram & $\begin{array}{l}\text { Chicken meat, which is processed with } \\
\text { the enzyme transglutaminase so that it } \\
\text { becomes impure chicken sausage. }\end{array}$ \\
\hline Haram & Halal & Haram & $\begin{array}{l}\text { Pork is mixed with halal flour and } \\
\text { becomes an impure stick. }\end{array}$ \\
\hline
\end{tabular}

Source: Jamaludin \& Radzi (2009) 


\section{Istihlak}

Istihlāk is also part of the purification of food and drinks to be pure and halal. Istihlāk is simply the process of destroying the shape of the smell, the color, and the taste of something. Destruction of form, color, and taste are the effects of mixing with other ingredients that melt their original nature. The merging of impure objects and the loss of their impure attributes is due to the greater amount of fusing material, and to sanctify it, this is called the istihlāk process. The basis for applying the istihlāk rules are two șahīh (authentic)hadiths narrated by al-Turmużì from Abū Sa'īd al-Khudrī, that the water is pure and nothing can defile it[13], and the hadith narrated by al-Dārimī from Ibn 'Umar that water could not be contaminated in the volume of at least two qullah(approximately 270 liters) [36].

\section{Gelatin Extraction or Production Method and Identification of Halal Critical Points}

Gelatin based on the extraction method from various sources of animal skin or bone is classified into two types: A and B[37]. Type A is the gelatin that pretreatment with acid and type B with base. Both acid and base pretreatment also affect the characteristics of the resulting gelatin. Type A gelatin has low molecular weight, low viscosity but high gel strength making it suitable for food products. Whereas type B gelatin has a large molecular weight so that viscosity is better, generally used in the pharmaceutical industries. Besides the acid and base methods, gelatin can also be extracted using enzymatic methods. The enzymes used are proteases, a class of enzymes that break down proteins[38]. In addition, a new method that combining an acid and base pretreatment has also been developed, although it can be categorized as gelatin type A gelatin[39].

The stages of gelatin extraction or production are: sorting raw materials; making pretreatment with acids and bases; extracting gelatin with water solvent; and filtration, deionization, and drying [40]. Based on this procedure, several halal critical points can be identified such as the source of raw materials, protease enzymes, ethanol, and filter material. The main raw material must be not pig or animals that are not slaughtered in the name of Allah. Halal sources such as cows or poultry must be monitored for the slaughtering process in accordance with Sharia law. Fish is the best alternative source because this ingredient has a halal guarantee. Another ingredient that needs to be monitored is the use of ethanol. Ethanol is an organic solvent that is sometimes used in the procedure. The material must be ascertained not sourced from the khamr industries[28].

Contaminated materials with haram content can be 'purified' by tahärah, such as in the cleaning of equipment, enzymes, and ethanol. If the enzym are sourced from non-pork carcasses or using ethanol in the process, then it can be 'purified' by washing with water. Nonpork enzymes and ethanol are not heavy najis (najis mugallazah), so washing is sufficient with two qullah waters. Even if it is categorized as heavy najis, adding soil does not make it difficult to separate it from gelatin. The soil used must be insoluble in water, so that it can separate from water-soluble gelatin. Washing must be done at the pre-treatment stage. The equipment used in the process must also be clean and avoid contamination of 'najis' substances, be it heavy, medium or mild najis.

\section{Conclusion}

As an alternative in the process of making gelatin, it should be considered the studies of istihālahistihlāk, and tahārah in halal analysis. The source of gelatin from fish and vegetable ingredients is an alternative for gelatin replacement whereas it has a very high halal guarantee. 


\section{References}

[1] [1] M. Tieman and M. C. Ghazali, "Halal Control Activities and Assurance Activities in Halal Food Logistics," Procedia - Soc. Behav. Sci., vol. 121, no. September 2012, pp. 44-57, 2014, doi: 10.1016/j.sbspro.2014.01.1107.

[2] K. Nakyinsige, Y. B. C. Man, and A. Q. Sazili, "Halal authenticity issues in meat and meat products," Meat Sci., vol. 91, no. 3, pp. 207-214, Jul. 2012, doi: 10.1016/j.meatsci.2012.02.015.

[3] A. Mursyidi, "The Role of Chemical Analysis in the Halal Authentication of Food and Pharmaceutical Products," J.Food Pharm.Sci., vol. 1, no. 2013, pp. 1-4, 2013.

[4] A. da T. Alfaro, E. Balbinot, C. I. Weber, I. B. Tonial, and A. Machado-Lunkes, "Fish Gelatin: Characteristics, Functional Properties, Applications and Future Potentials," Food Eng. Rev., vol. 7, no. 1, pp. 33-44, 2015, doi: 10.1007/s12393-014-9096-5.

[5] E. Ali et al., "Gelatin controversies in food, pharmaceuticals, and personal care products: Authentication methods, current status, and future challenges," Crit. Rev. Food Sci. Nutr., vol. 58, no. 9, pp. 1495-1511, 2018, doi: 10.1080/10408398.2016.1264361.

[6] A. Batu, J. M. Regenstein, and İ. S. Doğan, "Gelatin Issues in Halal Food Processing for Muslim Societies," Int. Period. Lang. Lit. Hist. Turkish, vol. 10, no. 14, pp. 37-52, 2015.

[7] H. I. Abdullah Amqizal, H. A. Al-Kahtani, E. A. Ismail, K. Hayat, and I. Jaswir, "Identification and Verification of Porcine DNA in Commercial Gelatin and Gelatin Containing Processed Foods," Food Control, vol. 78, pp. 297-303, 2017, doi: 10.1016/j.foodcont.2017.02.024.

[8] N. Hassan, T. Ahmad, and N. M. Zain, "Chemical and Chemometric Methods for Halal Authentication of Gelatin: An Overview," J. Food Sci., vol. 83, no. 12, pp. 2903-2911, 2018, doi: 10.1111/1750-3841.14370.

[9] W. F. Nugraha, "Vaccination(Immunization In The Perspective Of Islamic Law)," Perkolasi, vol. II, no. 1, pp. 1-10, 2018.

[10] M. A. Jamaludin and C. W. J. W. M. Radzi, "Teori Istihalah Menurut Perspektif Islam dan Sains: Aplikasi Terhadap Beberapa Penghasilan Produk Makanan,” J. Syariah, vol. 17, no. 1, pp. 169-194, 2009.

[11] M. A. Jamaludin, M. A. Ramli, D. M. Hashim, and S. A. Rahman, "Fiqh Istihalah: Integration of Science and Islamic Law," Revel. Sci., vol. 2, no. 02, pp. 117-123, 2012.

[12] S. M. R. bin S. Yūsuf, 'Ārif 'Alī 'Ārif, and L. Zakariyya, "The Impact of the Two Maxims of Istihāalah and Istihlāk upon the Rulings on Food and Medicine: An Analytical Juristic Study," Al-Majallah al- 'Ālamiyyah li al-Dirāsāt al-Fiqhiyyah wa al-Ușūliyyah, vol. 2, no. 2, pp. 6-17, 2018.

[13] M. bin 'Īsā Al-Turmużī, Sunan al-Turmuż̄i. Bairut: Dār al-Garb al-Islāmī, 1998.

[14] M. bin 'Alī Al-Syaukān̄i, Fatḥ al-Qadīr. Bairut: Dār al-Kalam al-Ṭayyib, 1414.

[15] A. bin 'Alī A. B. Al-Jașșāṣ, Ahkām al-Qur'ān. Bairut: Dār al-Kutub al-'Ilmiyyah, 1994.

[16] 'Alī bin Ahmad bin Sa'īd bin Hazm Al-Andalūsī, Marātib al-Ijmā' fì al- 'Ibādāt wa al-Mu 'àmalāt wa al-I'tiqāāât. Bairut: Dâr al-Kutub al-'Ilmiyyah.

[17] M. bin Al-Hajjāj, Șah̄̄h Muslim. Bairut: Dār Iḥyā al-Turās al-'Arab̄̄.

[18] Y. Al-Qarḍāwī, al-Halāl wa al-Halāl fi al-Islām. Kairo: Maktabah Wahbah, 2012. 
[19] M. bin Y. al-Q. Ibn Mājah, Sunan Ibn Mājah. Dār al-Risālah al-'Ālamiyah, 2009.

[20] I. bin 'Umar Ibn Kas̄īr, Tafsīr al-Qru'ān al-'Az̄ìm. Bairut: Dār al-Kutub al-'Ilmiyyah, 1419.

[21] M. bin J. Al-Ṭabarī, Jāmi 'al-Bayān fì Ta'wīl al-Qur'ān. Bairut: Muassasah alRisālah

[22] M. bin 'Abdillah A. B. Ibn Al-'Arab̄̄, Aḥkām al-Qur'ān. Bairut: Dār al-Kutub al'Ilmīyah.

[23] 'Abd al-Mun'im bin 'Abd Al-Raḥīm Ibn Al-Faras, Aḥkām al-Qur'ān. Bairut: Dār Ibn Hazm, 2006.

[24] A. A. A. bin M. Hanbal, Musnad Ahmad. Kairo: Dar al-Hadis, 1995.

[25] M. bin A. bin M. Ibn Rusyd, Bidāyah al-Mujtahid wa Nihāyah al-Muqtașid. Kairo: Dār al-Hadīìs, 2004.

[26] M. bin Y. bin Șalāḥ al-D. Al-Buhūtī, Kassyāf al-Qinā' $i$ 'an Matn al-Iqnā 'i. Bairut: Dâr al-Kutub al-'Ilmiyyah.

[27] MUI, Penggunaan Bulu, Rambut dan Tanduk dari Hewan Halal yang Tidak Disembelih Secara Syar'i untuk Bahan Pangan, Obat-Obatan dan Kosmetika. Indonesia, 2012.

[28] MUI, "Hukum alkohol," 2009.

[29] M. S. Al-Suyūțī, Mu juizāt fi al-Ṭibb li al-Nab̄̄ al-'Arabī Muhammad saw. Bairut: Muassasah al-Risālah, 1984.

[30] D. Suhendar, "Fikih (Fiqh) Air dan Tanah dalam Taharah (Thaharah) Menurut Perspektif Ilmu Kimia,” J. Kim. UIN Sunan Gunung Djati Bandung, vol. X, no. 1, pp. 170-193, 2017.

[31] I. Gagliardone, D. Gal, T. Alves, and G. Martinez, Countering online hate speech. UNESCO Publishing, 2015.

[32] A. W. Eriatna, "Antibacterial Activity of Clay Bentonite and Kaolin Soaps to Bacterial of Dog Saliva,” Universitas Islam Negeri Syarif Hidayatullah Jakarta, 2017.

[33] D. S. Wati, "Optimasi Formula Sabun Cair Bentonit Sebagai Penyuci Najis Mughalladzah Menggunakan Kombinasi Minyak Kelapa dan Minyak Kelapa Sawit Dengan Simplex Lattice Design," Universitas Gadjah Mada, 2015.

[34] W. bin M. Al-Zuḥailī, Al-Fiqh al-Islāmī wa Adillatuh, II. Bairut: Dār al-Fikr, 1985.

[35] 'Abdullah bin Aḥmad Ibn Qudāmah, al-Mugnī. Bairut: Dār al-Fikr, 1984.

[36] 'Abdullah bin 'Abd al-Raḥmān bin Faḍl Al-Dārimī, Sunan al-Dārimī. al-Mamlakah al-Sa'ūdiyyah: Dār al-Mugnī.

[37] R. Schreiber and H. Gareis., Gelatine Handbook: Theory and Industrial Practice. Wiley VCH, 2007.

[38] S. H. Hosseini-Parvar, J. Keramat, M. Kadivar, E. Khanipour, and A. Motamedzadegan, "Optimising conditions for enzymatic extraction of edible gelatinfrom the cattle bones using response surface methodology," Int. J. Food Sci. Technol., vol. 44, no. 3, pp. 467-475, 2009.

[39] G. Boran and J. M. Regenstein, "Optimization of gelatin extraction from silver carp skin,” J. Food Sci., vol. 74, no. 8, pp. E432-E441, 2009.

[40] G. G. Handbook, "Gelatin Manufacturers Institute of America," Inc., New York, NY, 2012. 